\title{
Mapping of the Pneumococcus Chromosome: Application of the Density-shift Method
}

\author{
By L. O. BUTLER AND M. B. SMILEY \\ Department of Medical Microbiology, St George's Hospital Medical School, \\ Hyde Park Corner, London, S.W. I
}

(Received 4 July 1972; revised 18 December 1972)

\begin{abstract}
SUMMARY
Conditions have been investigated which allow the mapping of the replication order of the genes on the pneumococcal chromosome by the density-shift method. Adequate synchrony of DNA replication was achieved by using cultures already involved in the strict regime designed to give competent cells; such cultures were grown for 30 min into the stationary phase and then diluted into the medium in which the density-shift will occur. The shift was achieved by changing from either (i) 'light' peptone medium to synthetic medium containing 5-BU, or (ii) peptone medium prepared in $\mathrm{D}_{2} \mathrm{O}$ to 'light' peptone medium. Samples of such cultures were lysed and centrifuged in caesium chloride and the gradients so formed fractionated and analysed for the transforming activity for the genetic markers. A map giving the order of replication of eleven markers is described.
\end{abstract}

\section{INTRODUCTION}

Although particular regions of the pneumococcus chromosome have been mapped, such as the aminopterin region (Sicard \& Ephrussi-Taylor, 1965), large-scale mapping has been neglected. Pneumococcus does not appear to conjugate or transduce, and therefore all genetic studies must be based on analysis by transformation. Linkage groups have so far only been described comparatively rarely, and hence it is necessary to apply one of the supporting techniques. Such techniques that have already been applied to the mapping of Bacillus subtilis include marker frequency (Yoshikawa \& Sueoka, I963a,b) and density shift (Yoshikawa \& Sueoka, 1963b; Oishi, Yoshikawa \& Sueoka, I964; Oishi \& Sueoka, 1965; Dubnau, Smith \& Marmur, I965; Oishi, Oishi \& Sueoka, 1966; O’Sullivan \& Sueoka, 1967; Dubnau, Goldthwaite, Smith \& Marmur, 1967), and the technique chosen in this study was that of density shift. When this method was first formulated, it was thought that the bacterial chromosome replicated uni-directionally from a single initiation point (Cairns, I963 $a, b$; Nagata, I963; Yoshikawa \& Sueoka, I963a,b), and hence the replication order of the markers would be identical to the genetical order. More recently, however, evidence has been presented supporting bi-directional replication from a single initiation point (Caro \& Berg, I968, 1969; Nishioka \& Eisenstark, I970; Masters \& Broda, I97I; Yahara, I97I; Wake, I972; R. E. Bird, J. Louarn \& L. G. Caro, personal communication). Such a mechanism, however, does not invalidate the usefulness of the map of the replication order which provides, at least for pneumococcus, a basis on which genetic evidence from transformation studies can be placed. It does require that the evidence be interpreted with this reservation in mind, and indeed, results to be presented in a subsequent paper will show that the order of replication of the pneumococcus chromosome is not in agreement with 
Table I. Description of the pneumococcal strains used

Strain

$\begin{array}{ll}\begin{array}{l}\text { Clone } 3\left(\mathrm{cl}_{3}\right) \\ \text { Strain } \mathrm{I} 4\end{array} & \begin{array}{l}\text { Wild-type } \\ \text { ade }\end{array} \\ \text { Strain 15 } & \begin{array}{l}p a b-A \\ p a b-B\end{array} \\ \text { Strain 16 } & a m p-A \\ \text { Amp-03 } & \\ \text { Amp-06 } & a m p-B\end{array}$

$\mathrm{AmIr}_{2} \mathrm{SQ}$

$\mathrm{TC}_{3} \mathrm{r}_{2} \mathrm{SQ}$

3Amp3AmIr $2 \mathrm{SQ}$

AmI
Ic3Amir $_{2} \mathrm{SQ}$
3Amp3

amiA-rI
Genotype

Recipients

\section{Donors}

amiA-rI ery-r2 str-r4I opt-r2 tet-A ery-r2 str-r4I opt-r2

amp- $A$ amp-B amp-C amiA-rI ery-r2 str-r4I opt-r2

Others

tet-A amiA-rI ery-r2 str-r4I opt-r2 amp-A amp-B amp-C
Remarks

$$
\begin{aligned}
& \text { Isolated by NNG mutagenesis;* } \\
& \text { requires } 40 \mu \mathrm{g} \text { adenine/ml. } \\
& \text { Isolated by NNG mutagenesis;* } \\
& \text { requires I } 6 \mathrm{~g} \text {-amino-benzoic } \\
& \text { acid/ml. } \\
& \text { Isolated by NNG mutagenesis;* } \\
& \text { confers resistance to } 0.03 \mu \mathrm{g} \text { ampi- } \\
& \text { cillin } / \mathrm{ml} \text {. } \\
& \text { Isolated by NNG mutagenesis;* } \\
& \text { confers resistance in presence of } \\
& \text { amp- } A \text { to } 0.06 \mu \mathrm{g} \text { ampicillin } / \mathrm{ml} \text {. }
\end{aligned}
$$

tet- $A$ was isolated by NNG mutagenesis;* confers resistance to I $2 \mu \mathrm{g}$ tetracycline $/ \mathrm{ml}$.

amp-C was isolated by NNG mutagenesis;* confers resistance in presence of $a m p-A$ and $a m p-B$ to $0.09 \mu \mathrm{g}$ ampicillin $/ \mathrm{ml}$.

Derived by the addition of the three ampicillin loci by transformation.

* Butler \& Smiley (1970).

the genetical data, giving supporting evidence that in pneumococcus also replication is bi-directional from a single initiation point.

The successful use of the density-shift method depends on being able to obtain good synchrony with respect to the synthesis of deoxyribonucleic acid (DNA) and on the ability of the organisms to take up substances which would result in a density shift of the DNA. The method for obtaining the required synchrony will be described. The uptake of deuterium, given as $\mathrm{D}_{2} \mathrm{O}$, by pneumococci has been described by Martin \& Ephrussi-Taylor (1964), and by Firshein \& Schwenzfeier (I969). Deuterium has been used in the work described, but results will be presented to show that pneumococci may also take up sufficient quantities of 5-bromouracil to result in a good density shift. By the use of these techniques, a start has been made in mapping the genes on the pneumococcus chromosome in terms of their order of replication.

\section{METHODS}

Organisms. The wild-type strain used was the transformable strain of Diplococcus pneumoniae known as Clone 3 ( $\left.\mathrm{Cl}_{3}\right)$, derived from strain R36A of Avery, MacLeod \& McCarty (I944) by Ephrussi-Taylor (I95I). All other strains as listed in Table I were derived from the strain $\mathrm{Cl}_{3}$ either by transformation or by mutagenesis of strain $\mathrm{Cl}_{3}$ by $\mathrm{N}$-methyl$N$-nitro- $N$-nitrosoguanidine (NNG) as previously described (Butler \& Smiley, 1970). The antibiotic resistance markers obtained by mutagenesis were transferred on to strain $\mathrm{Cl}_{3}$ by transformation. 


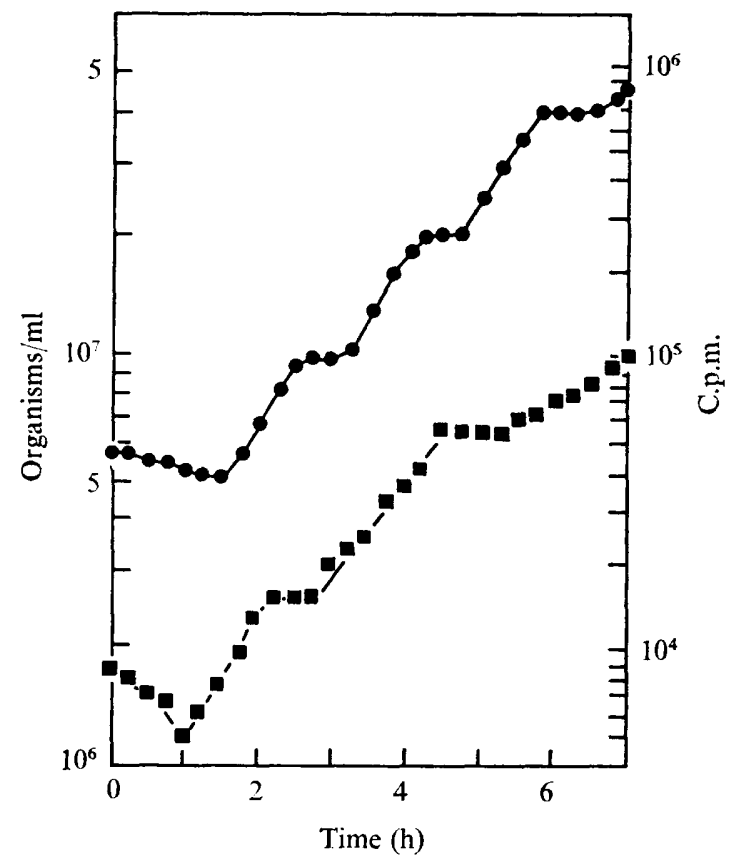

Fig. I. Growth (O) and $\left[{ }^{3} \mathrm{H}\right]$ thymidine uptake $(\square)$ curves of strain $A m I r_{2} S Q$ in 5 -BU-S medium containing $\left[{ }^{3} \mathrm{H}\right]$ thymidine, inoculated from the stationary phase grown in 'preculture medium'.

Stock cultures were maintained as previously described (Butler, I965). Briefly, stock cultures were grown in supplemented ' $\mathrm{P}$ ' medium containing L-glutamine, DL-asparagine, fresh yeast extract and defibrinated horse blood at concentrations of $315 \mu \mathrm{g} / \mathrm{ml}, 20 \mu \mathrm{g} / \mathrm{ml}$, $2 \%(\mathrm{v} / \mathrm{v})$ and $2 \%(\mathrm{v} / \mathrm{v})$ respectively. The culture was incubated for $2 \frac{1}{2} \mathrm{~h}$ at $37^{\circ} \mathrm{C}$ and then stored at $4{ }^{\circ} \mathrm{C}$ for use the following day.

General growth media. The peptone media 'P' and 'NS' (Sicard, I964; Butler, 1965), and the synthetic medium of Sicard (1964) were prepared as previously described. The fresh yeast extract was prepared as described by Sicard (1964).

Medium for growth of auxotrophic mutants. The synthetic medium of Sicard was used as the base with supplementation by the appropriate chemical at the required concentration as shown in Table I.

Media for density labelling. (i) 5-Bromouracil (Koch-Light Laboratories Ltd, Colnbrook, Buckinghamshire) was added to the synthetic medium of Sicard at a concentration of $2.2 \mathrm{mg} 5-\mathrm{BU} / \mathrm{ml}$ in place of the uracil usually contained in the Sicard medium. Such a medium was designated as ' 5 -BU-S' medium. (ii) Deuterated ' $\mathrm{P}$ ' medium was prepared by replacing the glass distilled water by $\mathrm{D}_{2} \mathrm{O}$ (Koch-Light) containing $\geqslant 99.7$ atom $\% \mathrm{D}$. All solutions added to the basic ' $\mathrm{P}$ ' medium were also prepared in $\mathrm{D}_{2} \mathrm{O}$ but the $\mathrm{pH}$ was adjusted by a solution of $\mathrm{NaOH}$ dissolved in $\mathrm{D}_{2} \mathrm{O}$. The strain grown in this medium (3Amp3 $\mathrm{Amlr}_{2} \mathrm{SQ}$ ) was first 'adapted' by culturing successively in media containing $20 \%, 40 \%$ and $80 \%$ $\mathrm{D}_{2} \mathrm{O}$ before finally culturing in $100 \% \mathrm{D}_{2} \mathrm{O}$ medium.

Synchronization of cultures. The procedure adopted to produce a workable degree of synchronization was the stationary phase method based on that described by Cutler \& Evans (I966). From the stock culture, i.e. one which had been maintained in the strict regime of at least three daily subculturing as described above, a preculture was prepared 
in the same medium but without added horse blood (the 'preculture medium'), making a I : 20 dilution. The culture was incubated at $37^{\circ} \mathrm{C}$ until $30 \mathrm{~min}$ after the stationary phase had begun, and was then cooled in ice, washed twice if necessary, and a sample transferred to the medium in which synchrony was required.

Using strain $\mathrm{AmIr}_{2} \mathrm{SQ}$, the stationary phase was attained after about a 3 -h incubation. After a 2ro-min incubation the culture was cooled and washed twice in the salts-amino acid solution which forms part of the Sicard medium, and finally suspended in the same volume of 5-BU-S medium. A I : 100 dilution of this was made in warm 5-BU-S medium containing $\left[{ }^{3} \mathrm{H}\right]$ thymidine (> I0000 $\mathrm{mCi} / \mathrm{mmol}$; Radiochemical Centre, Amersham, Buckinghamshire) at a concentration of $0.05 \mathrm{ml} / \mathrm{IO} \mathrm{ml}$ culture (on average $0.5 \mu \mathrm{g}\left[{ }^{3} \mathrm{H}\right]$ thymidine/Io ml culture) and incubated at $37^{\circ} \mathrm{C}$. The viable count and incorporation curves obtained over a $7 \mathrm{~h}$ period are shown in Fig. I, from which it can be seen that the culture was showing satisfactory synchrony of cell division and of DNA replication. The division time had lengthened to about $90 \mathrm{~min}$ and three discontinuous waves of division occurred during the period of observation, each wave representing a doubling. The $\left[{ }^{3} \mathrm{H}\right]$ thymidine incorporation curve was not so clear, however.

The strain is not thymidine-requiring, and as the culture had not been previously grown in the presence of $\left[{ }^{3} \mathrm{H}\right]$ thymidine, the DNA had not become fully labelled with ${ }^{3} \mathrm{H}$. The second plateau at $4 \frac{1}{2} \mathrm{~h}$ is, in fact, four times the plateau at $2 \frac{1}{4} \mathrm{~h}$, with no clear evidence of a plateau at the intermediate doubling, whilst it is probable that the $7 \mathrm{~h}$ figure would be the start of the next plateau, corresponding to another doubling of the DNA, if the interval between the discontinuities is maintained. The production of synchrony was not surprising since discontinuity of division and $\left[{ }^{3} \mathrm{H}\right]$ thymidine incorporation had been observed many times with pneumococcal cultures prepared from stocks in a way designed to obtain competence (Butler, 1970).

Since this experiment showed that the DNA synthesis was discontinuous and had signs of following the synchrony of the cell division, in further experiments only the pattern of cell division was taken as the criterion of synchrony. Although it might be implied that the DNA synchrony was not perfect, the results of the density-shift experiments (to be described) showed that the synchrony was certainly sufficient to allow ordering of the markers. Strain $\mathrm{TC}_{3} \mathrm{Am} \mathrm{Ir}_{2} \mathrm{SQ}$ gave only two synchronous divisions in the 5-BU-S medium after which the number of viable cells rapidly fell off, but strain $\mathrm{Tc}_{3} \mathrm{r}_{2} \mathrm{SQ}$ entered the stationary phase at about $220 \mathrm{~min}$ and inoculation of 5-BU-S medium with a washed suspension taken at 250 min gave synchronous growth for three generations with a 90-min division time. Strain $3 \mathrm{Amp} 3$ will not grow in the synthetic medium of Sicard so that it was not possible to use the 5 -BU-S medium to initiate the density shift. Hence it was decided to use deuterium as the density marker. Related pneumococci grow slowly in deuterated medium (Martin \& Ephrussi-Taylor, 1964), so it was more convenient to prepare the stationary phase culture in the deuterated medium and sample from 'light' $P$ medium. After strain $3 \mathrm{Amp}_{3} \mathrm{AmI}_{2} \mathrm{SQ}$ had been adapted to the deuterated ' $\mathrm{P}$ ' medium as described above, it was found necessary to incubate stock cultures for $8 \mathrm{~h}$ to obtain growth comparable to that in light ' $\mathrm{P}$ ' medium. The stationary phase was reached after some $10 \mathrm{~h}$ of incubation, but was maintained for only $2 \mathrm{~h}$ before the cell count began to fall rapidly. However, a I: IO dilution of a $10 \frac{1}{2} \mathrm{~h}$ culture in 'preculture medium' gave synchronous growth over four generations with a 40-min generation time.

Determination of the order of replication. A culture labelled with ${ }^{3} \mathrm{H}$ and growing synchronously with respect to DNA synthesis and to cell division as described under 'synchronization of cultures', in either 5-BU-S medium if the parental DNA is of 'light' density or in 
nutrient medium if the parental DNA is of 'heavy' density, had $40 \mathrm{ml}$ samples removed at varying times. The samples were cooled immediately in ice, washed twice in cold Sicard medium without uracil, and resuspended in $1.0 \mathrm{ml}$ of $0.0 \mathrm{I}$ M-EDTA in $0.15 \mathrm{~N}-\mathrm{NaCl}$ at $\mathrm{pH} 8.5$. Lysis was accomplished by the addition of $0 . \mathrm{I} \mathrm{ml} 5 \%(\mathrm{w} / \mathrm{v})$ deoxycholate solution and incubating for $30 \mathrm{~min}$ at $37^{\circ} \mathrm{C}$. A saturated caesium chloride solution $(2.6 \mathrm{ml})$ containing $0.00 \mathrm{I} \mathrm{M-tris} \mathrm{and} 0.0005 \mathrm{M}$-EDTA were carefully added to a $0.7 \mathrm{ml}$ sample of the lysate and the mixture adjusted to a refractive index of between $\mathrm{I} \cdot 3980$ and $\mathrm{I} \cdot 4050$, depending on the density of the parental DNA, measured at $20^{\circ} \mathrm{C}$ with an Abbé refractometer. The density gradient was then formed by centrifuging in a SW 39 head in a Spinco model L ultracentrifuge for $50 \mathrm{~h}$ at $35000 \mathrm{rev}$. $/ \mathrm{min}$ at $24^{\circ} \mathrm{C}$. After centrifugation, the bottom of the centrifuge tube was punctured and two-drop fractions collected. Three drops near the beginning and three drops near the end of the fractionation were measured for their refractive index so that the density gradient over the whole tube could be interpolated. Each fraction was then assayed for ${ }^{3} \mathrm{H}$ and for the transforming activity for the several markers present.

\section{Assay for radioactivity}

Samples from density gradients. In earlier experiments, the assay was carried out on Io $\mu \mathrm{l}$ samples of each of the density-gradient fractions which had been dried on to a $15 \mathrm{~mm}$ square of $3 \mathrm{MM}$ Whatman filter paper and immersed in a scintillation fluid composed of $5 \mathrm{~g}$ 2,5-diphenyloxazole (PPO) and 0.3 g I,4-bis-2-(4-methyl-5-phenyloxazole)-benzene (dimethyl POPOP) in $\mathrm{I} \cdot 01$ toluene, and counted in a Packard 'Tri-Carb' scintillation counter. The majority of the assays were carried out on Io $\mu$ l of each of the fractions in Io $\mathrm{ml}$ of scintillation fluid containing $5 \mathrm{~g}$ 2-(4'-tert-butylphenyl)-5-(4"-biphenyl)-I,3,4oxadiozole (butyl-PBD) dissolved in a mixture of $300 \mathrm{ml}$ 2-ethoxyethanol and $700 \mathrm{ml}$ toluene. The samples were then counted in an Intertechnique ABAC 40 scintillation counter.

Samples from cell cultures. Samples $(\mathrm{I} \cdot \mathrm{\circ} \mathrm{ml})$ of a test culture were added to $\mathrm{I} \cdot 0 \mathrm{ml}$ of $10 \%(\mathrm{w} / \mathrm{v})$ trichloracetic acid containing $0.2 \mu \mathrm{g}$ 'cold' thymidine and kept on ice. The suspensions were then filtered through three thicknesses of Millipore membranes of $0.45 \mu \mathrm{m}$ porosity each, the bottles containing the suspensions washed out four times with $5 \%(\mathrm{w} / \mathrm{v})$ trichloracetic acid and the washings filtered through the same membranes, and the filter washed twice more with $5 \%(\mathrm{w} / \mathrm{v})$ trichloracetic acid and twice with $\mathrm{I} \%(\mathrm{v} / \mathrm{v})$ acetic acid. A set of these membranes were washed in the same way at the beginning and at the end of the series, and at intermediate places if desirable, to act as controls. The membranes were dried in air at room temperature and each membrane put into the bottom of a vial to which was added scintillation fluid containing $5 \mathrm{~g}$ butyl-PBD/l toluene. The samples were then counted in the Intertechnique scintillation counter.

Assay of transforming activity. The method used was essentially as described previously (Butler, 1965). Assay of the auxotrophic markers was accomplished by transforming to wild-type and hence the screening was done by plating directly on to Sicard medium without supplements. Samples $(5 \mu \mathrm{l})$ of the $\mathrm{CsCl}$ gradient fractions were used for assay; higher concentrations of $\mathrm{CsCl}$ interfered with the transformation process, as reported by Martin \& Ephrussi-Taylor (1964).

Assay of viable count. A sample of culture was taken and suitable dilutions were plated in triplicate in deep culture in nutrient agar containing horse blood. The colonies grown in the plates after 24 to $36 \mathrm{~h}$ of incubation were counted and the average of the triplicate platings calculated. At the same time, another sample from the culture was taken and 
Table 2. Toxicity of 5-bromouracil in synthetic medium

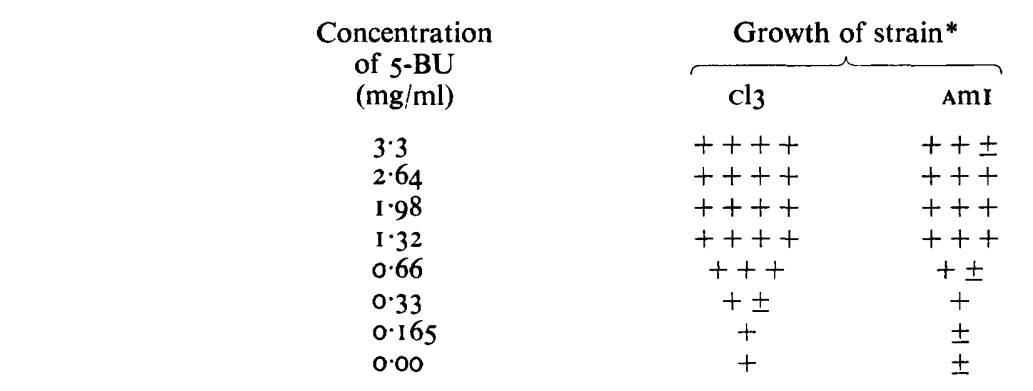

* Represented as gradation of turbidity from \pm (just discernible turbidity) to ++++ (highly turbid).

immediately mixed with methylene blue. An average figure for the chain length was calculated by examination of the fresh preparation under a coverslip with the oil-immersion lens and recording the number of chains and the number of organisms in each chain in a large number of fields; the average chain length was then derived by dividing the total number of cells observed by the number of chains. The average colony count was then multiplied by the average chain length to give the 'corrected viable count'.

\section{Growth in 5-bromouracil}

\section{RESULTS}

The toxicity of 5 -bromouracil was ascertained by observing the turbidity caused by the growth of strains $\mathrm{Cl}_{3}$ and AmI in the synthetic medium of Sicard (I964) in which the uracil had been replaced by increasing quantities of 5-bromouracil. Cultures were first prepared in ' $P$ ' medium, washed in the salts-amino acid solution which forms part of the Sicard medium, and then resuspended in the Sicard medium from which uracil had been omitted. This suspension was used to inoculate tubes containing synthetic medium in which was dissolved the various concentrations of $5-\mathrm{BU}$, and the resulting cultures incubated overnight. The growth in each tube was then assessed visually and given arbitrary plus ratings. The results are summarized in Table 2 and it can be seen that these strains grew well in quite high concentrations of 5 -BU. There were some signs that the highest concentrations used (which was near to the maximum solubility of 5-BU) might be having some toxic effects, so that it was decided to use the 5 -BU at a concentration of $2 \cdot 2 \mathrm{mg} / \mathrm{ml}$ in the 5-BU-S medium.

\section{Determination of the replication order}

Three strains have been used for the preparation of lysates for density gradients. Each strain was grown in ' $P$ ' medium as 'stock' cultures on two successive days, but in the presence of $\left[{ }^{3} \mathrm{H}\right]$ thymidine, and on the third day grown $30 \mathrm{~min}$ into the stationary phase, also in the presence of $\left[{ }^{3} \mathrm{H}\right]$ thymidine. This treatment induced synchrony and also radioactively labelled the parental DNA. An appropriate sample was then inoculated, after washing, into medium containing a different density label, sampled after suitable periods of incubation, lysed, centrifuged in $\mathrm{CsCl}$, and fractionated. The fractions were first assayed for ${ }^{3} \mathrm{H}$ which pin-pointed the fractions containing the parental and hybrid bands. These fractions together with those expected to contain the fully replicated band were then assayed for their transforming activity. 
Table 3. Density-shift experiments with strain $\mathrm{A} m \mathrm{I} r_{2} \mathrm{SQ}$ from ' $P$ ' medium to 5-BU-S medium (percentage of total number of transformants of each marker in each density band)

\begin{tabular}{|c|c|c|c|c|c|c|}
\hline \multirow[b]{2}{*}{ Expt } & \multirow[b]{2}{*}{$\begin{array}{l}\text { Time of } \\
\text { sampling } \\
\text { (h) }\end{array}$} & \multirow[b]{2}{*}{ Marker } & \multirow[b]{2}{*}{$\begin{array}{c}\text { Total } \\
\text { number of } \\
\text { transformants }\end{array}$} & \multicolumn{3}{|c|}{ Total transformants in each band $(\%)$} \\
\hline & & & & $\begin{array}{c}\text { Light } \\
\text { (parental) }\end{array}$ & Hybrid & Heavy \\
\hline $\mathbf{I}$ & $3 \frac{3}{4}$ & $\begin{array}{l}\text { opt-r2 } \\
\text { ery-r2 } \\
s t r-r 4 I\end{array}$ & $\begin{array}{r}248 \\
792 \\
206 \mathrm{I}\end{array}$ & $\begin{array}{l}93.55 \\
95 \cdot 96 \\
99 \cdot 27\end{array}$ & $\begin{array}{l}6 \cdot 45 \\
4 \cdot 04 \\
0 \cdot 73\end{array}$ & $\begin{array}{l}0 \\
0 \\
0\end{array}$ \\
\hline 2 & $4 \frac{1}{2}$ & $\begin{array}{l}\text { opt-r2 } \\
\text { ery-r2 } \\
\text { str-r4I }\end{array}$ & $\begin{array}{l}1332 \\
5137 \\
9524\end{array}$ & $\begin{array}{l}81 \cdot 30 \\
82 \cdot 30 \\
84 \cdot 90\end{array}$ & $\begin{array}{l}18 \cdot 70 \\
17 \cdot 70 \\
15 \cdot 10\end{array}$ & $\begin{array}{l}\circ \\
\circ \\
\circ\end{array}$ \\
\hline & 5 & $\begin{array}{l}\text { ade } \\
\text { opt-r2 } \\
\text { ery-r2 } \\
\text { str-r4I }\end{array}$ & $\begin{array}{r}5695 \\
2439 \\
8480 \\
12376\end{array}$ & $\begin{array}{l}30 \cdot 29 \\
32 \cdot 09 \\
35 \cdot 00 \\
41 \cdot 50\end{array}$ & $\begin{array}{l}65 \cdot 50 \\
66 \cdot 50 \\
65 \cdot 00 \\
58 \cdot 50\end{array}$ & $\begin{array}{l}4 \cdot 2 \mathrm{I} \\
\mathrm{I} \cdot 4 \mathrm{I} \\
0 \\
0\end{array}$ \\
\hline 3 & 5 & $\begin{array}{l}p a b-A \\
o p t-r 2 \\
p a b-B \\
a m i A-r I \\
\text { ery-r2 }\end{array}$ & $\begin{array}{r}4525 \\
4106 \\
16305 \\
17559 \\
9721\end{array}$ & $\begin{array}{l}23 \cdot 10 \\
31 \cdot 10 \\
49 \cdot 95 \\
62 \cdot 30 \\
62 \cdot 30\end{array}$ & $\begin{array}{l}74 \cdot 60 \\
68 \cdot 00 \\
50 \cdot 05 \\
37 \cdot 70 \\
37 \cdot 70\end{array}$ & $\begin{array}{l}2 \cdot 30 \\
0.90 \\
0.00 \\
0.00 \\
0.00\end{array}$ \\
\hline 4 & $5 \frac{3}{4}$ & $\begin{array}{l}\text { opt-r2 } \\
\text { ery-r2 } \\
\text { str-r4I }\end{array}$ & $\begin{array}{r}3043 \\
10578 \\
19572\end{array}$ & $\begin{array}{l}3 \cdot 20 \\
5 \cdot 80 \\
6 \cdot 40\end{array}$ & $\begin{array}{l}95 \cdot 00 \\
94 \cdot 20 \\
93 \cdot 60\end{array}$ & $\begin{array}{l}\mathrm{I} \cdot 88 \\
0 \\
0\end{array}$ \\
\hline 5 & 6 & $\begin{array}{l}\text { ade } \\
\text { opt-r2 } \\
\text { ami } A-r I \\
\text { ery-r2 } \\
\text { str-r4I }\end{array}$ & $\begin{array}{r}4059 \\
9479 \\
78395 \\
28166 \\
95348\end{array}$ & $\begin{array}{l}0 \\
0 \\
0 \\
0 \\
0\end{array}$ & $\begin{array}{r}89 \cdot 79 \\
98 \cdot 66 \\
99 \cdot 72 \\
100 \cdot 00 \\
100 \cdot 00\end{array}$ & $\begin{array}{l}\text { IO.2 I } \\
\text { I.44 } \\
0 \cdot 28 \\
0 \\
0\end{array}$ \\
\hline 6 & 7 & $\begin{array}{l}\text { ade } \\
\text { opt-r2 } \\
\text { amiA-rI } \\
\text { ery-r2 } \\
\text { str-r4I }\end{array}$ & $\begin{array}{r}2286 \\
5871 \\
13329 \\
12333 \\
29644\end{array}$ & $\begin{array}{l}0 \\
0 \\
0 \\
0 \\
0\end{array}$ & $\begin{array}{l}64 \cdot 40 \\
98 \cdot 06 \\
99 \cdot 25 \\
99 \cdot 65 \\
99 \cdot 95\end{array}$ & $\begin{array}{r}35.60 \\
I .93 \\
0.75 \\
0.35 \\
0.05\end{array}$ \\
\hline
\end{tabular}

Mapping with strain $\mathrm{A} m \mathrm{I} r_{2}$ SQ. The density shift was attained by inoculating at a $\mathrm{I}$ in 100 dilution a washed synchronized culture into 5-BU-S medium. Samples were taken at various incubation times between $3 \frac{3}{4}$ and $7 \mathrm{~h}$ inclusive, and the transforming activities of the gradient fractions for the markers ade, opt-r2, ery-r2, str-r4I, pab-A, amiA-rI and pab-B assayed. The number of transformants for each marker in each fraction was expressed as the percentage of the total number of transformants in all fractions and the percentages then plotted against the fraction number. The number of transformants for each marker in each peak expressed as a percentage of the total number of transformants for that marker were also calculated, and the results are set out in Table 3. The density of each band was also determined from the refractive index readings, and these were found to be $\mathrm{I} \cdot 695 \mathrm{~g} \mathrm{~cm}^{-3}$ for the parental light band, $I \cdot 713 \mathrm{~g} \mathrm{~cm}^{-3}$ for the hybrid band, and $\mathrm{r} \cdot 730 \mathrm{~g} \mathrm{~cm}^{-3}$ for the fully replicated heavy band. The figure for the light band (I.695) compares with other published figures of $\mathrm{I} \cdot 698 \mathrm{~g} \mathrm{~cm}^{-3}$ (Ephrussi-Taylor, I960, I96I), I.700 $\mathrm{g} \mathrm{cm}^{-3}$ (Marmur \& Schildkraut, I96I) and I·70I $\mathrm{g} \mathrm{cm}^{-3}$ (Firshein \& Schwenzfeier, I969).

The results show the relative order of these markers as:

$$
\text { origin- } \left.\begin{array}{c}
a d e \\
p a b-A
\end{array}\right\}-o p t-r 2-p a b-B-a m i A-r I-e r y-r 2-s t r-r 4 I .
$$




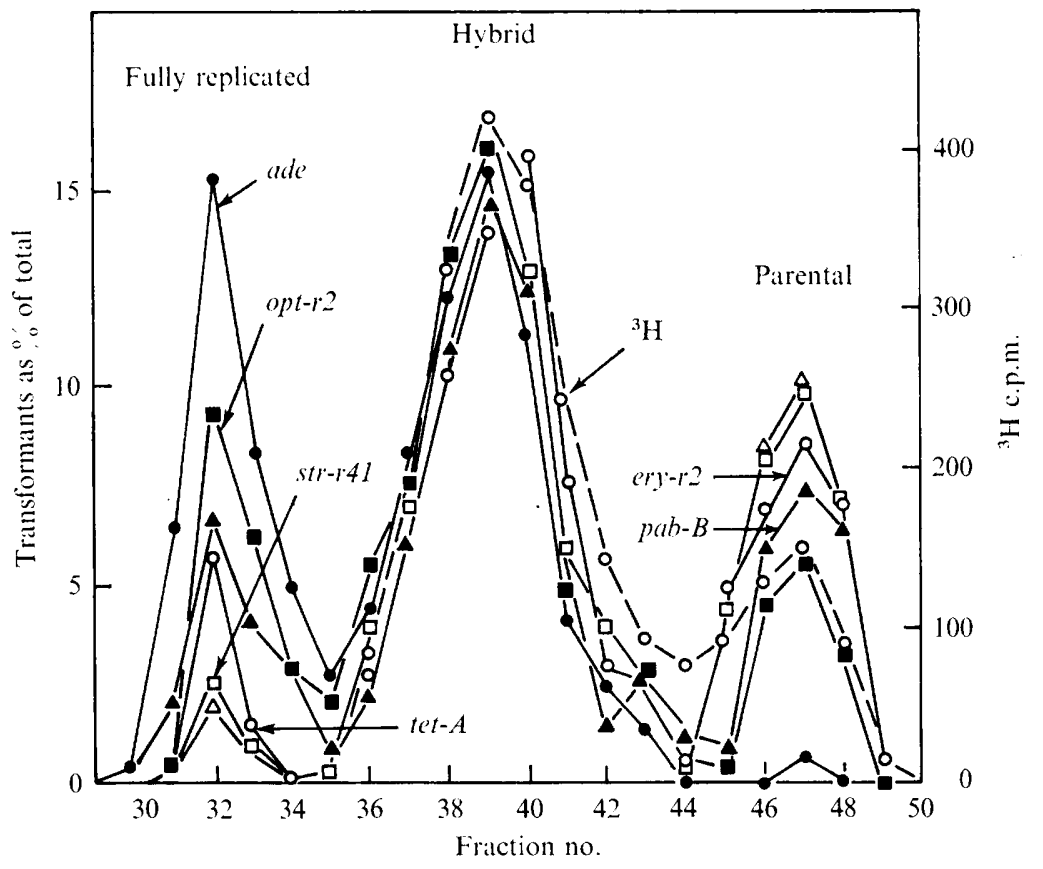

Fig. 2. Distribution of ${ }^{3} \mathrm{H}$ label (--O--) and of the transforming activity for the markers ade (O),

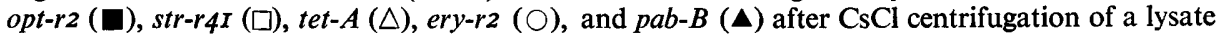
of $\left[{ }^{3} \mathrm{H}\right]$ thymidine-labelled strain $\mathrm{Tc}_{3} \mathrm{r}_{2} \mathrm{SQ}$ grown for $5 \mathrm{~h}$ in 5 -BU-S medium.

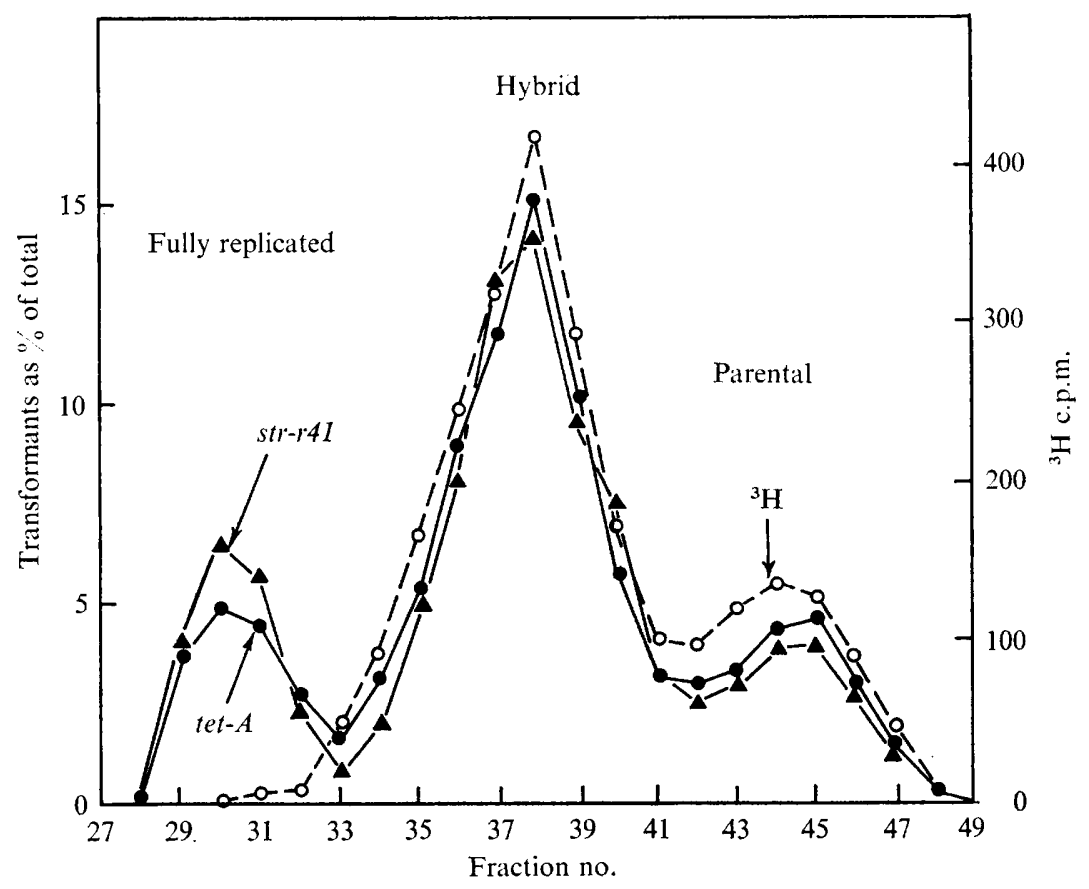

Fig. 3. Distribution of ${ }^{3} \mathrm{H}$ label $(O)$ and of the transforming activity for the markers str-r4I $(\Delta)$ and tet-A (๑) after $\mathrm{CsCl}$ centrifugation of a lysate of $\left[{ }^{3} \mathrm{H}\right]$ thymidine-labelled strain $\mathrm{Tc}_{3} \mathrm{r}_{2} \mathrm{SQ}$ grown for $5 \frac{1}{2} \mathrm{~h}$ in 5 -BU-S medium. 
Table 4. Density-shift experiments with strain $\mathrm{T} c 3 r_{2} \mathrm{SQ}$ from ' $P$ ' medium to 5-BU-S medium (percentage of total number of transformants of each marker in each density band)

\begin{tabular}{|c|c|c|c|c|c|c|}
\hline \multirow[b]{2}{*}{ Expt } & \multirow{2}{*}{$\begin{array}{l}\text { Time of } \\
\text { sampling } \\
\text { (h) }\end{array}$} & \multirow[b]{2}{*}{ Marker } & \multirow{2}{*}{$\begin{array}{c}\text { Total } \\
\text { number of } \\
\text { transformants }\end{array}$} & \multicolumn{3}{|c|}{ Total transformants in each band $(\%)$} \\
\hline & & & & $\begin{array}{c}\text { Light } \\
\text { (parental) }\end{array}$ & Hybrid & Heavy \\
\hline \multirow[t]{11}{*}{$\mathbf{I}$} & 4 & ade & 5430 & $42 \cdot 60$ & $54 \cdot 34$ & 3.06 \\
\hline & & $p a b-A$ & 7473 & $44 \cdot 90$ & 54.60 & 0.47 \\
\hline & & $o p t-r 2$ & 7203 & $50 \cdot 00$ & $49 \cdot 75$ & 0.25 \\
\hline & & ery-r2 & I 5590 & $50 \cdot 32$ & $49 \cdot 60$ & 0.08 \\
\hline & & str-r $4 I$ & 43473 & $52 \cdot 65$ & $47 \cdot 35$ & 0.00 \\
\hline & & tet $-A$ & 24751 & $52 \cdot 65$ & $47 \cdot 35$ & 0.00 \\
\hline & $4 \frac{3}{4}$ & $p a b-A$ & 9253 & $10 \cdot 00$ & 83.00 & 7.00 \\
\hline & & opt-r2 & 9107 & II 30 & 87.80 & 0.90 \\
\hline & & ery-rz & 18072 & 13.40 & $86 \cdot 60$ & 0.00 \\
\hline & & str-r $4 I$ & 45210 & 13.80 & $86 \cdot 20$ & 0.00 \\
\hline & & tet $-A$ & 23946 & $15 \cdot 60$ & $84 \cdot 40$ & 0.00 \\
\hline \multirow[t]{4}{*}{2} & $5 \frac{1}{2}$ & str-r4I & 6 I 439 & $15 \cdot 80$ & $64 \cdot 80$ & $19 \cdot 40$ \\
\hline & & $t e t-A$ & 59766 & $18 \cdot 00$ & $65 \cdot 40$ & \\
\hline & $6 \frac{1}{2}$ & str-r4I & $7559 \mathrm{I}$ & 0.00 & $72 \cdot 60$ & $27 \cdot 40$ \\
\hline & & tet-A & 73219 & 0.00 & $73 \cdot 40$ & $26 \cdot 80$ \\
\hline \multirow[t]{6}{*}{3} & 5 & ade & 5686 & $1 \cdot 00$ & $62 \cdot 10$ & $36 \cdot 90$ \\
\hline & & $o p t-r 2$ & $423 I$ & I 3.90 & 65.50 & 20.60 \\
\hline & & $p a b-B$ & II 347 & $21 \cdot 90$ & $6 \mathrm{I} \cdot 60$ & 16.50 \\
\hline & & ery-r2 & $867 \mathrm{I}$ & $28 \cdot 20$ & $64 \cdot 00$ & $7 \cdot 80$ \\
\hline & & str-r4I & 16520 & $30 \cdot 40$ & $65 \cdot 50$ & $4 \cdot 10$ \\
\hline & & $t e t-A$ & 15980 & 31.00 & 65.60 & $3 \cdot 40$ \\
\hline
\end{tabular}

Mapping with strain $\mathrm{T} c 3 r_{2} \mathrm{SQ}$. The density shift was attained using synchronous cultures prepared in the same way as those of strain $\mathrm{AmI}_{2} \mathrm{SQ}$, and finally sampled from a culture growing in 5-BU-S medium. The relative percentages of transformants were calculated as before, and representatives of the curves obtained, together with the ${ }^{3} \mathrm{H}$ profiles are shown in Fig. 2 and 3. The relative percentages of transformants are given in Table 4 . In this way, the relative order of ade and $p a b-A$ was determined, the order of the other five markers confirmed and the position of tet- $A$ determined. It can be seen that $p a b-A$ occurs between ade and opt-r2, and that tet- $A$ is placed after str-r4I. It will be seen that it was necessary to take quite late samples before being able to differentiate the streptomycin and tetracycline loci.

The replication order is thus:

$$
\text { origin-ade-pab-A-opt-r2-pab-B-amiA-rI-ery-r2-str-r4I-tet-A. }
$$

Mapping with strain $3 \mathrm{Amp} 3 \mathrm{Am} \mathrm{I} r_{2} \mathrm{SQ}$. In this case the density shift was attained by passing from $\mathrm{D}_{2} \mathrm{O}$-medium to light medium taking a $\mathrm{I}$ in Io dilution of the synchronized 'heavy' culture. The density of the fully deuterated band was $1 \cdot 7 \mathrm{I} 5 \mathrm{~g} \mathrm{~cm}^{-3}$, which compares with the figure of 1.719 given by Marmur \& Schildkraut (196I). Typical curves are shown in Fig. 4, and the relative percentages in Table 5. The results confirmed the previous replication order of markers, and also placed the three ampicillin markers before ade in the order amp-B-amp-A-amp-C-. The ampicillin markers now become the earliest markers to be mapped, and could be positioned satisfactorily by using only the hybrid band without the necessity of sampling at later incubation times when the fully replicated band would have appeared. 


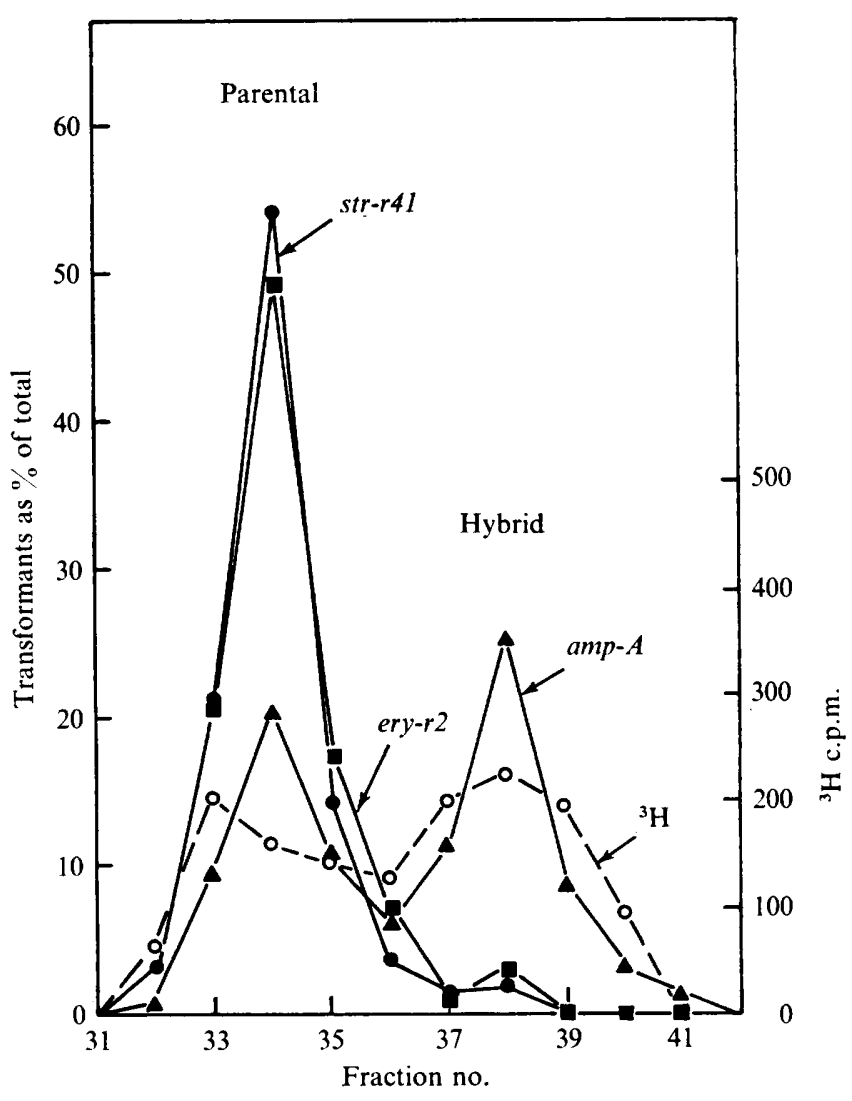

Fig. 4. Distribution of ${ }^{3} \mathrm{H}$ label $(O)$ and of the transforming activity for the markers str-r4I $(\bullet)$,

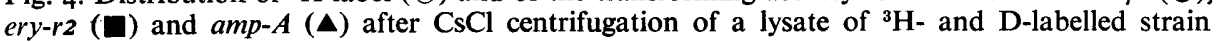
$3 \mathrm{Amp} 3 \mathrm{AmIr}_{2} \mathrm{SQ}$ grown for $50 \mathrm{~min}$ in ' $\mathrm{P}$ ' medium.

The replication order of the markers mapped so far is:

origin-amp-B-amp-A-amp-C-ade-pab-A-opt-r2-pab-B-amiA-rI-ery-r2-str-r4I-tet-A.

\section{DISCUSSION}

It is of interest to note that the pneumococci were able to grow well in the 5 -BU medium. This strain is not thymine-requiring, whilst the only purine or pyrimidine included in the Sicard (1964) medium is uracil. Omission of the uracil results in poor growth probably dependent on the inoculum size. This strain therefore appears to have a block for uracil. It might have been that the sample of $5-\mathrm{BU}$ was contaminated with uracil which allowed the growth of the organism but the makers claim that their product contains no free uracil. However, the 5-BU was not toxic and sufficient amounts of 5-BU were incorporated to allow good separation of the parental, hybrid and fully replicated DNA in the density gradient. There is no reason to suppose that the label was not randomly distributed.

Any doubts that may have persisted regarding the synchronization of the cultures were dispelled by the fact that all markers were not found distributed in each of the bands separated in the density gradient at each time of sampling. Indeed samples taken at different 


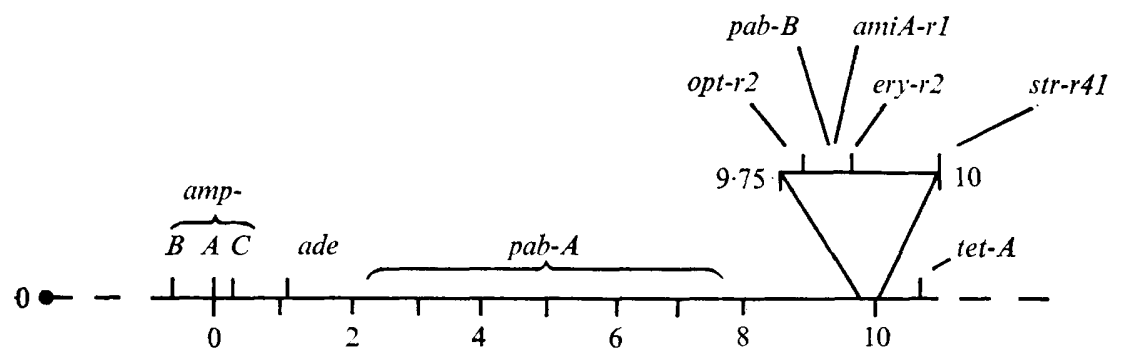

Fig. 5. Map of the pneumococcal chromosome derived from density-shift experiments.

Table 5. Density-shift experiments with strain $3 \mathrm{Amp} 3 \mathrm{Am} \mathrm{r}_{2} \mathrm{SQ}$ from $\mathrm{D}_{2} \mathrm{O}$ medium to $\mathrm{H}_{2} \mathrm{O}$ medium (percentage of total number of transformants of each marker in each density band)

\begin{tabular}{|c|c|c|c|c|c|c|}
\hline \multirow[b]{2}{*}{ Expt } & \multirow{2}{*}{$\begin{array}{l}\text { Time of } \\
\text { sampling } \\
\text { (min) }\end{array}$} & \multirow[b]{2}{*}{ Marker } & \multirow{2}{*}{$\begin{array}{c}\text { Total } \\
\text { number of } \\
\text { transformants }\end{array}$} & \multicolumn{3}{|c|}{ Total transformants in each band $(\%)$} \\
\hline & & & & $\begin{array}{c}\text { Heavy } \\
\text { (parental) }\end{array}$ & Hybrid & Light \\
\hline \multirow[t]{3}{*}{ I } & 50 & $a m p-A$ & 895 & $44 \cdot 40$ & $53 \cdot 60$ & 0.00 \\
\hline & & ery-rz & 1523 & $96 \cdot 70$ & $3 \cdot 30$ & 0.00 \\
\hline & & str-r4I & 3276 & $97 \cdot 40$ & $2 \cdot 60$ & 0.00 \\
\hline \multirow[t]{5}{*}{2} & 75 & $a m p-B$ & 1859 & 14.90 & $85 \cdot 10$ & 0.00 \\
\hline & & amp- $A$ & 1781 & 16.85 & $83 \cdot 15$ & 0.00 \\
\hline & & ade & 1342 & 18.00 & 82.00 & 0.00 \\
\hline & & $o p t-r 2$ & 1262 & $27 \cdot 40$ & $72 \cdot 60$ & 0.00 \\
\hline & & $p a b-B$ & $369 I$ & $27 \cdot 80$ & $72 \cdot 20$ & 0.00 \\
\hline \multirow[t]{4}{*}{3} & 95 & $a m p-B$ & 2010 & 10.90 & $89 \cdot 10$ & 0.00 \\
\hline & & $a m p-A$ & 2141 & 14.85 & $85 \cdot 15$ & 0.00 \\
\hline & & $a m p-C$ & 1825 & $16 \cdot 30$ & 83.70 & 0.00 \\
\hline & & ade & 2747 & $2 I \cdot 80$ & $78 \cdot 20$ & 0.00 \\
\hline \multirow[t]{6}{*}{4} & 60 & $a m p-A$ & 1012 & $41 \cdot 80$ & $58 \cdot 20$ & 0.00 \\
\hline & & $a m p-C$ & 9893 & $59 \cdot 60$ & $40 \cdot 40$ & $0 . \infty 0$ \\
\hline & & ade & 1307 & $76 \cdot 50$ & 23.50 & 0.00 \\
\hline & 90 & $a m p-A$ & 1921 & 6.50 & 93.50 & 0.00 \\
\hline & & $a m p-C$ & 1950 & $9 \cdot 80$ & $90 \cdot 20$ & 0.00 \\
\hline & & ade & $242 \mathrm{I}$ & $20 \cdot 50$ & 79.50 & 0.00 \\
\hline
\end{tabular}

times showed both a progressive increase in the activity of the markers, and the appearance of new markers in the new bands, both patterns being consistently repeatable on a number of different occasions.

It has been shown that the density-shift method can be used to determine the replication order of markers in these strains of pneumococci, and hence the beginnings of a general map of the pneumococcal chromosome in terms of the order of replication has been presented. The relative positions of opt-r2, ery-r2, amiA-rI and str-r4I markers agree with the order given by clonal analysis (Louarn \& Sicard, 1969). Although it was clear that good synchrony was attained, it took about three divisions before all the parental band had disappeared. Because of this, it is difficult to make a meaningful estimate of the distance of the markers from the initiation point of the chromosome; it can be said that $a m p-B$ is not far from the beginning of its replicon and tet- $A$ is not far from the end of its replicon. An attempt can be made of estimating the relative distances between each marker from the percentage transformants appearing in either the hybrid band or the fully replicated band, 
taking the results where only two bands existed for the particular set of genes. If three bands exist, then the figures for the hybrid band are the resultant of not only the replication from the parental band but also the replication of the hybrid band itself producing both fully replicated and hybrid DNA. Hence a better approximation of the relative distances can be obtained by using only those results from those experiments where only two bands existed and also where it can be sure that the round of replication represented by that sample had, in fact, reached the marker concerned. For example, in experiment 3 in Table 3 , it cannot be certain that the figure for the amiA-rI marker can be used in calculations in relation to those for the markers before it. Bearing these restrictions in mind, the distance between the $a m p-A$ marker and str-r4I marker was taken as 10.00 units and it was found that the relation of all the other markers could be calculated except for amiA-rI, $p a b-A$ and $p a b-B$. The map so obtained is shown in Fig. 5. It can be seen that the markers mapped so far fall into two distinct groups situated towards each end of the chromosome. It is interesting to note that ade occurs towards the beginning of the chromosome as do the ade markers of Bacillus subtilis (Dubnau et al. 1967; O'Sullivan \& Sueoka, 1967), but the streptomycin and erythromycin loci are not similar in their positions nor in their order.

More markers will be mapped in this way, and the presence of linkage between the markers is being looked for.

Thanks are due to the Medical Research Council for a grant to support this work.

\section{REFERENCES}

Avery, O. T., MacLeod, C. M. \& McCarty, M. (1944). Studies on the chemical nature of the substance inducing transformation of pneumococcal types. Induction of transformation by a desoxyribonucleic acid fraction isolated from Pneumococcus type III. Journal of Experimental Biology 89, I37-I 57.

ButLer, L. O. (1965). A co-precipitation method for the preparation of transforming DNA from small samples of low density bacterial cultures. Journal of General Microbiology 39, 247-252.

Butler, L. O. (1970). Sintesi dell'ocido desossiribonucleico nei batteri. Recenti Progressi in Medicina 49, 303-326.

ButLer, L. O. \& SmiLey, M. B. (1970). Characterization by transformation of an ampicillin-resistant mutant of pneumococcus. Journal of General Microbiology 61, I 89-195.

CAIRNs, J. (1963a). The bacterial chromosome and its manner of replication as seen by autoradiography. Journal of Molecular Biology 6, 208-213.

CAIRNs, J. (1963 b). The chromosome of Escherichia coli. Cold Spring Harbor Symposia of Quantitative Biology 28, $43-46$.

CARO, L. G. \& BERG, C. M. (I968). Chromosome replication in some strains of Escherichia coli K I2. Cold Spring Harbor Symposium of Quantitative Biology 33, 559-573.

CARo, L. G. \& Berg, C. M. (1969). Chromosome replication in Escherichia coli. II. Origin of replication in $\mathrm{F}^{-}$and $\mathrm{F}^{+}$strains. Journal of Molecular Biology 45, 325-336.

CutLer, R. G. \& Evans, J. E. (1966). Synchronisation of bacteria by a stationary-phase method. Journal of Bacteriology 91, 469-476.

Dubnau, D., Goldthwaite, C., Smith, I. \& Marmur, J. (1967). Genetic mapping in Bacillus subtilis. Journal of Molecular Biology 27, 163-185.

Dubnau, D., Smith, I. \& Marmur, J. (1965). Gene conservation in Bacillus species. II. The location of genes concerned with the synthesis of ribosomal components and soluble RNA. Proceedings of the National Academy of Sciences of the United States of America 54, 724-730.

EphrusSI-TAYLOR, H. (195I). Transformations allogènes du pneumocoque. Experimental Cell Research 2, 589-607.

EphruSSI-TAYLOR, H. (I960). L'état du DNA transformant au cours des premières phases de la transformation bactérienne. Comptes rendus des séances de la Société de biologie 154, 195I-1955.

Ephrussi-Taylor, H. (196I). Étude de la recombinason à l'échelle moléculaire de la transformation bactérienne. Journal de chimie physique et de physico-chemie biologique 58, 1090-1099. 
FirsheIN, W. \& SCHWENZFEIER, W. C. (1969). Characterization of excess deoxyribonucleic acid synthesized by pneumococci in the presence of polyadenylic acid and deoxyribonucleic acid precursors. Journal o, Bacteriology 97, I I06-III 3 .

LOUARN, J-M. \& SICARD, A. M. (1969). Identical transformability of both strands of recipient DNA in Diplococcus pneumoniae. Biochemical and Biophysical Research Communications 36, I0I-109.

MarmuR, J. \& SCHILdKRaUt, C. L. (196I). Growth of bacteria labelled with heavy isotopes for the isolation of nucleic acids. Nature, London $189,636-638$.

Martin, C. \& EPHRUSSI-TAYLOR, H. (1964). Effects of partial deuteration on transforming DNA of pneumococcus. Biochemica and biophysica acta 80, $4 \mathrm{I} \mathrm{I}-42 \mathrm{I}$.

MASTERS, M. \& BRODA, P. (1971). Evidence for the bidirectional replication of the Escherichia coli chromosome. Nature New Biology 232, $137-140$.

NAGATA, T. (1963). The molecular synchrony and sequential replication of DNA in Escherichia coli. Proceedings of the National Academy of Sciences of the United States of America 49, 55I-559.

NishiokA, Y. \& Eisenstark, A. (1970). Sequence of genes replicated in Salmonella typhimurium as examined by transduction techniques. Journal of Bacteriology 102, 320-333.

OIsHI, M., OISHI, A. \& SuEOKA, N. (1966). Location of genetic loci of soluble RNA on Bacillus subtilis chromosome. Proceedings of the National Academy of Sciences of the United States of America 55, 1095-IIO3.

OISHI, M. \& SUEOKA, N. (1965). Location of genetic loci of ribosomal RNA on Bacillus subtilis chromosome. Proceedings of the National Academy of Sciences of the United States of America 54, 483-49I.

Oishi, M., Yoshikawa, H. \& Sueoka, N. (1964). Synchronous and dichotomous replications of the Bacillus subtilis chromosome during spore germination. Nature, London 204, I069-1073.

O'Sullivan, A. \& Sueoka, N. (1967). Sequential replication of Bacillus subtilis chromosome. IV. Genetic mapping by density transfer experiments. Journal of Molecular Biology 27, 349-368.

SiCARD, A. M. (1964). A new synthetic medium for Diplococcus pneumoniae and its use for the study of reciprocal transformation at the amiA locus. Genetics 50, 31-44.

SiCARD, A. M. \& EPHRUSSI-TAYLOR, H. (1965). Genetic recombination in DNA-induced transformation of pneumococcus. II. Mapping the amiA region. Genetics 52, $1207-1227$.

WAKE, R. G. (1972). Visualisation of re-initiated chromosomes in Bacillus subtilis. Journal of Molecular Biology 68, 50I-509.

YAHARA, I. (197I). On the replication of Escherichia coli chromosome. Journal of Molecular Biology 57, 373-376.

YoshiKaWA, H. \& SueOKA, N. (1963a). Sequential replication of Bacillus subtilis chromosome. I. Comparison of marker frequencies in exponential and stationary growth phase. Proceedings of the National Academy of Sciences of the United States of America 49, 559-566.

Yoshikawa, H. \& SueOKa, N. (1963b). Sequential replication in Bacillus subtilis chromosome. II. Isotopic transfer experiments. Proceedings of the National Academy of Sciences of the United States of America 49, 806-8I 3 . 